\title{
Upaya Meningkatkan Kemampuan Komunikasi Matematis dan Aktivitas Belajar Siswa Menggunakan Model Problem Based Learning
}

\author{
Emma Ratna Anggraeni Soleh ${ }^{1, *}$, Wawan Setiawan' ${ }^{2}$, Rozadira Haqi ${ }^{3}$ \\ 1,2,3 Universitas Pasundan \\ *emmaratnaanggraenisoleh1995@gmail.com \\ \begin{tabular}{|l|l|l|}
\hline Received : $15-1-2020$ & Revised: $5-3-2020$ & Accepted: $7-3-2020$ \\
\hline
\end{tabular}
}

\begin{abstract}
ABSTRAK
Penelitian ini bertujuan untuk mengetahui peningkatan dan pengaruh model problem based learning terhadap kemampuan komunikasi matematis. Penelitian ini dilakukan di SMA Negeri 1 Mande Cianjur. Peneliti menentukan subjek penelitian adalah siswa kelas X di SMA Negeri 1 Mande, dengan objek penelitiannya adalah penerapan model problem based learning. Metode yang digunakan adalah penelitian tindakan kelas (PTK) dengan sampel sebanyak 34 siswa kelas X IPS 2. Penelitian di laksanakan sebanyak 3 siklus, dan dengan materi yang di ujikan adalah materi fungsi. Pembelajaran dengan materi fungsi pada siklus 1 adalah 28,82. Yang tuntas hanya 1 siswa dengan persentase $2,8 \%$, sedangkan siswa yang belum tuntas ada 33 siswa dengan persentase 97,2\%. Peningkatan hasil belajar matematika materi fungsi diperoleh data siswa tuntas pada siklus II ada 21 siswa yang tuntas dengan persentase 61,8\%, sedangkan siswa yang belum tuntas ada 13 siswa dengan persentase $38,2 \%$. Pada siklus III terjadi peningkatan yang cukup signifikan yaitu siswa yang tuntas menjadi 25 siswa dengan prosentase $75,76 \%$, sedangkan siswa yang belum tuntas 9 siswa dengan presentase $24,24 \%$. Artinya secara keseluruhan kelas dapat dikatakan tuntas.
\end{abstract}

Kata Kunci : Kemampuan Komunikasi Matematis, Problem based learning

\section{ABSTRACT}

This study aims to determine the increase and influence of problem based learning models on mathematical communication ability. This research was conducted at Mande Cianjur 1 High School. Researchers determine the subject of research is class X students in SMA Negeri 1 Mande, with the object of research is the application of problem based learning models. The method used was classroom action research (CAR) with a sample of 34 students of class X IPS 2. The study was carried out as many as 3 cycles, and the material being tested was functional material. Learning with the material function in cycle 1 is 28.82. Only one student completed with a percentage of $2.8 \%$, while students who had not completed were 33 students with a percentage of $97.2 \%$. Improvement of mathematics learning outcomes for functional materials obtained by complete student data in cycle II there were 21 students who completed with a percentage of $61.8 \%$, while students who had not completed 13 students with a percentage of $38.2 \%$. In cycle III there was a significant increase in students who completed to 25 students with a percentage of $75.76 \%$, while students who had not completed 9 students with a percentage of $24.24 \%$. This means that the whole class can be said to be complete.

Keywords: Mathematical Communication Ability, Problem based learning 


\section{PENDAHULUAN}

Proses pembelajaran yang terjadi disekolah masih perlu perbaikan - perbaikan. Hal ini seperti yang disampaikan oleh Sudarman bahwa salah satu masalah yang dihadapi dunia pendidikan kita adalah masalah lemahnya proses pembelajaran (Wardani, Widodo, \& Priyani, 2011). Dalam proses pembelajaran matematika banyak siswa yang mengalami hambatan yang dapat kita lihat dari sikap belajar maupun hasil penilaian yang rendah. Dalam sikap belajar matematika siswa yang mempunyai hambatan terlihat bersikap pasif, dan masa bodoh. Sedangkan siswa yang tidak mengalami kesulitan terlihat aktif, bersemangat dan berkonsentrasi dalam pembelajaran. Dari data yang diambil mengenai rerata nilai harian dalam 2 tahun terakhir pada materi Fungsi pada sekolah tempat penelitian didapat pada tahun 2017 adalah 58 dan pada tahun 2018 adalah 60. Hal ini jika dikaitkan dengan KKM sekolah yang berlaku saat itu yaitu 70 maka didapat masih banyak siswa yang belum tuntas mencapai KKM.

Rendahnya hasil belajar mengindikasikan ada sesuatu yang salah dan belum optimal dalam pembelajaran disekolah (Muslim, 2014). Biasanya aktivitas pembelajaran perpusat pada guru, materi pembelajaran disampaikan melalui ceramah, sehingga siswa bersikap pasif. Sehingga mengakibatkan lemahnya kemampuan komunikasi matematis siswa dan lemahnya aktivititas siswa dalam belajaran matematika. Fakta dilapangan bahwa kemampuan komunikasi matematis siswa masih rendah. Merujuk pada penelitian yang dilakukan oleh (Anggriani \& Septian, 2019), bahwa hasil analisis yang telah dilakukan menunjukan rata-rata kemampuan komunikasi matematis masih tergolong rendah. Oleh karena itu, sebaiknya guru dapat banyak memberikan stimulus soal-soal kemampuan komunikasi matematik Untuk meningkatkan kemampuan komunikasi matematik siswa (Wijayanto, Fajriah, \& Anita, 2018).

Komunikasi merupakan bagian yang sangat penting dalam kegiatan pembelajaran. Menurut Bistari ((Putra, 2017) mengatakan bahwa komunikasi merupakan bagian yang tak terpisahkan dalam kehidupan, begitu juga dalam proses pembelajaran matematika. $70 \%$ waktu manusia digunakan untuk berkomunikasi, komunikasi menentukan kualitas hidup manusia. Sejalan dengan itu NCTM juga menyampaikan bahwa Komunikasi merupakan kemampuan yang sangat penting dalam kegiatan pembelajaran, dan harus dikembangkan. Hal ini dikarenakan melalui komunikasi, gagasan-gagasan atau ide-ide menjadi objek refleksi, penghalusan, bahan diskusi dan perbaikan (Putra, 2017).

Greenes dan schulman (Umar, 2012) menyatakan komunikasi matematika merupakan : (1) kekuatan sentral bagi siswa dalam merumuskan konsep dan strategi 
matematik; (2) modal keberhasilan bagi siswa terhadap pendekatan dan penyelesaian dalam eksplorasi dan investigasi matematik; (3) wadah bagi siswa dalam berkomunikasi dengan temannya untuk memperoleh informasi, berbagi pikiran dan penemuan, curah pendapat, menilai dan mempertajam ide untuk meyakinkan orang lain . Menurut NCTM (Umar, 2012) menyatakan bahwa omunikasi matematika perlu menjadi fokus perhatian dalam pembelajaran matematika, sebab melalui komunikasi, siswa dapat mengorganisasi dan mengkonsolidasi berpikir matematisnya.

Menurut NCTM (Lee, 2015) standar tentang "komunikasi”, program dari pra-TK hingga kelas 12 harus mempersiapkan semua siswa untuk: (1) mengatur dan mengkonsolidasikan pemikiran matematika mereka melalui komunikasi; mengkomunikasikan pemikiran matematis mereka secara koheren dan jelas kepada teman sebaya, guru, dan orang lain; (3) menganalisis dan mengevaluasi pemikiran matematis dan strategi orang lain; dan (4) menggunakan bahasa matematika untuk mengekspresikan ide matematika.

Menurut Hendriana (Novtiar \& Aripin, 2017) merinci indikator komunikasi matematis ke dalam beberapa kegiatan matematis, antara lain: a) Menyatakan benda-benda nyata, situasi, dan peristiwa sehari-hari ke dalam bentuk model matematika (gambar, tabel, diagram, grafik, ekpresi aljabar; b) Menjelaskan ide, dan model matematika gambar, tabel, diagram, grafik, ekspresi aljabar) ke dalam bahasa biasa; c) Menjelaskan dan membuat pertanyaan matematika yang di pelajari; d) Mendengarkan, berdiskusi, dan menulis tentang matematika; e) Membaca dengan pemahaman suatu presentasi tertulis; dan f) Membuat konjektur, menyusun argumen, merumuskan definisi dan generalisasi. Indikator butir a) sama dengan butir c) merupakan pedoman dalam menyusun suatu tes matematika tertulis. Sedangkan semua indikator di atas digunakan untuk mengembangkan kemampuan komunikasi matematis selama dalam pembelajaran.

Selain kemampuan komunikasi matematis yang masih rendah, juga aktivitas siswa dalam belajar matematika masih belum opimal, kondisi ini dapat terindikasi dari banyak siswa yang pasif ketika pembelajaran berlangsung. Hal ini sependapat dengan Rahmadani yang menyatakan bahwa Aktivitas siswa dalam pembelajaran terbatas pada aktivitas mendengarkan guru dan diskusi, tidak ada aktivitas lain yang mendukung proses pembelajaran. Pengelolaan pembelajaran yang demikian akan menyebabkan aktivitas belajar siswa tidak optimal (Rahmadani \& Anugraheni, 2017).

Menurut Usman (Rahmadani \& Anugraheni, 2017) menggolongkan aktivitas belajar siswa ke dalam beberapa hal sebagai berikut, aktivitas visual, aktivitas lisan, 
aktivitas mendengarkan, aktivitas gerak, aktivitas menulis. Menurut Dierich yang dikutip Hamalik menyatakan bahwa aktivitas belajar dibagi menjadi delapan kelompok yaitu, Kegiatan-kegiatan visual, kegiatan-kegiatan lisan (oral), kegiatan-kegiatan mendegarkan, kegiatan-kegiatan menulis, kegiatan-kegiatan menggambar, kegiatan-kegiatan metrik, kegiatan-kegitan mental, kegiatan-kegiatan emosional (Rahmadani \& Anugraheni, 2017).

Dalam usaha untuk menyelesaikan permasalahan kemampuan komunikasi matematis dan aktivitas belajar siswa tidak terlepas dari kemampuan guru dalam mengelola kelas yang tentunya berhubungan dengan model pembelajaran yang dipergunakan oleh guru dalam pembelajaran dikelas. Salah satunya adalah model problem based learning (PBL). Pengambilan model problem based learning berdasarkan penelitian (Septian \& Rizkiandi, 2017) dengan judul "Penerapan Model problem based learning (PBL) Terhadap Peningkatan Kemampuan Berpikir Kreatif Matematis Siswa”. Model problem based learning merupakan salah satu model dalam pembelajaran yang membantu siswa untuk mengembangkan aktivitas siswa dalam pembelajaran. Menurut Septian (Julyanasari, Praja, Noto, Sunan, \& Djati, 2019) model PBL adalah model pembelajaran yang menekankan pada penyediaan masalah sehingga dapat melatih peserta didik untuk berpikir kritis, menganalisis dan memecahkan masalah yang kompleks. Pendidikan yang berkualitas dapat ditingkatkan melalui melatih pemikiran menggunakan model pembelajaran yang tepat (Maskur et al., 2020).

PBL memberikan tantangan kepada siswa, bekerja bersama dalam suatu kelompok untuk menyelesaikan suatu permasalahan. PBL dirancang untuk membantu guru memberikan informasi sebanyakbanyaknya kepada siswa melalui suatu permasalahan. PBL membantu siswa untuk mengembangkan keterampilan berpikir dan keterampilan mengatasi masalah, mempelajari orang dewasa dan menjadi pelajar yang mandiri (Simarmata, Wibowo, Hutajulu, \& Hendriana, 2018). PBL memberikan tantangan kepada siswa untuk bisa bekerja bersama dalam suatu kelompok dalam menyelesaikan suatu permasalahan. PBL dirancang untuk membantu guru memberikan informasi sebanyakbanyaknya kepada siswa melalui suatu permasalahan.

Berdasarkan latar belakang di atas, maka masalah yang dikaji dalam penelitian ini adalah apakah penggunaan model problem based learning (PBL) dapat meningkatkan kemampuan komunikasi matematis siswa dan bagaimana pengaruh penggunaan model problem based learning (PBL) terhadap aktivitas belajar siswa pada materi Fungsi. 


\section{METODE PENELITIAN}

Jenis penelitian yang digunakan adaalah penelitian tindakan kelas (Classroom Action Research). Menurut Arikunto bahwa penelitian tindakan kelas adalah penelitian tindakan yang bersifat reflektif dan kolaboratif dan dilakukan dengan tujuan untuk memperbaiki mutu praktek pembelajaran di kelas (Widayanti, 2013). Langkah - langkah metode yang digunakan dalam penelitian ini peneliti menggunakan deskriptif kuantitatif yaitu membandingkan hasil tindakan pada tiap siklus. Penelitian tindakan kelas ini terdiri dari empat tahapan, yakni (1) perencanaan (planning), (2) pelaksanaan (acting), pengamatan (observing), dan (4) refleksi (reflecting). Setelah melakukan tindakan refleksi yang mencakup analisis, sintesis dan penilaian terhadap hasil pengamatan proses dan hasil tindakan yang dilakukan, biasanya timbul permasalahan atau pemikiran yang perlu mendapat perbaikan, sehingga perlu dilakukan perencanaan ulang, tindakan ulang, pengamatan ulang, serta refleksi ulang.

Penelitian ini ditentukan dengan tindakan sebanyak 3 siklus. Pra siklus dilakukan sebelum mulai melaksanakan siklus I, II, dan III. Pra siklus dilakukan dengan melihat kenyataan kelas serta nilai hasil ulangan harian sub pokok bahasan bentuk dan unsur-unsur perbandingan serta suku sejenis dan tidak sejenis bentuk perbandingan. Tujuannya ialah agar peneliti mengetahui gambaran yang tepat mengenai kondisi siswa dalam kelas, kesulitan yang dialami oleh siswa, masalah-masalah yang dihadapi oleh siswa dan penyebab dari masalah-masalah tersebut. Hal itu bisa menjadi pedoman, apakah sudah ada kesesuaian antara permasalahan yang tengah dihadapi siswa dengan model yang akan digunakan.

Dari hasil ulangan harian dan catatan harian, peneliti juga dapat mengetahui kemampuan awal. Hasil perolehan ini dapat dijadikan acuan bagi peneliti dalam memberikan perlakuan terhadap siswa selama penelitian. Setelah memperoleh data secara lengkap melalui pra siklus, barulah peneliti melakukan tahapan selanjutnya yaitu siklus I. Setelah siklus I melalui empat tahapan yaitu planning (perancanaan tindakan), acting (pelaksanaan tindakan), observing (pengamatan hasil tindakan), dan reflecting (refleksi hasil pengamatan). Dilanjutkan dengan siklus II melalui empat tahap yaitu planning (perancanaan tindakan), acting (pelaksanaan tindakan), observing (pengamatan hasil tindakan), dan reflecting (refleksi hasil pengamatan). Setelah itu, dilanjutkan dengan siklus III. Dalam penelitian ini kami membatasi sampai siklus III saja. 


\section{HASIL DAN PEMBAHASAN}

Siklus 1 dilaksanakan 2 kali pertemuan yang dilaksanakan pada hari Rabu, 09 Januari 2019 dan senin, 14 Januari 2019. Pada pertemuan pertama beberapa siswa belum sepenuhnya memperhatikan sungguh-sungguh penjelasan guru yang menyinggung materi tentang fungsi, hal ini terlihat dari aktivitas siswa yang terkesan main-main dan hanya melihat saja. Namun guru terus memberikan bimbingan dan arahan agar lebih serius. Sehingga dalam menyelesaikan LKS 1 siswa masih mengalami kesulitan dengan adanya kurang konsentrasi pada penjelasan materi oleh guru. Pada pertemuan ke 2, barulah diberikan materi mengenai fungsi yang lebih jelas. Adapun hasil observasi aktivitas siswa pada pertemuan pertama dapat dilihat pada tabel berikut ini :

Tabel 1. Observasi Aktivitas Siswa Siklus 1

\begin{tabular}{clc}
\hline No & \multicolumn{1}{c}{ Fokus Pengamatan } & Siswa \\
\hline 1 & Motivasi siswa mengikuti pembelajaran & Kurang \\
\hline 2 & $\begin{array}{l}\text { Memperhatikan dan mengikuti penjelasan } \\
\text { materi dengan model problem based learning }\end{array}$ & Kurang \\
\hline 3 & Menyelesaikan soal-soal pada LKS & Kurang \\
\hline
\end{tabular}

Berdasarkan Tabel 1, diketahui bahwa memperhatikan dan mengikuti proses belajar dengan model problem based learning serta menyelesaikan soal-soal LKS yang diberikan oleh guru masih dalam kategori kurang, sehingga membutuhkan perbaikan dalam rencana siklus berikutnya.

Di kegiatan akhir pertemuan pertama ini, peneliti langsung mengadakan LKS . Hasil LKS siswa pada siklus pertama dapat kita lihat pada Tabel 2.

Tabel 2. Hasil Siklus 1

\begin{tabular}{cc}
\hline Rata-Rata Skor Siswa & 28,82 \\
\hline Siswa Tuntas & 1 \\
\hline Siswa Tidak Tuntas & 33 \\
\hline
\end{tabular}

Berdasarkan Tabel 2, rata-rata hasil belajar siswa materi fungsi pada siklus 1 adalah 28,82. Yang tuntas hanya 1 siswa dengan persentase $2,8 \%$, sedangkan siswa yang belum tuntas ada 33 siswa dengan persentase 97,2\%. Setelah mengkaji hasil siklus 1 ternyata masih di bawah KKM yang telah ditentukan yaitu 68 .

Jika dilihat dari kriteria keberhasilan belajar siswa maka dapat dikatakan hasil belajar masih rendah. Jika kita lihat perbandingan antara siswa yang tuntas dan tidak tuntas, siswa yang tidak tuntas masih besar prosentasenya, sedangkan siswa yang tuntas di bawah 50\%. Sehingga dapat dikatakan untuk ketuntasan secara klasikal masih sangat 
rendah. Selama pelaksanaan berlangsung, guru membuat catatan harian tentang situasi dan kondisi guru, siswa, dan lingkungan. Pada siklus ini, kondisi guru dalam keadaan sehat.

Untuk siklus II ada dua kali pertemuan. Pertemuan ini dilaksanakan pada hari Jumat, tanggal 16 januari 2019. Adapun hasil observasi aktivitas siswa pada pertemuan kedua siklus II dapat dilihat pada Tabel 3.

Tabel 3. Observasi Aktivitas Siswa Siklus II

\begin{tabular}{cll}
\hline No & \multicolumn{1}{c}{ Fokus Pengamatan } & Siswa \\
\hline 1 & Motivasi siswa mengikuti pembelajaran & Cukup \\
\hline 2 & $\begin{array}{l}\text { Memperhatikan dan mengikuti penjelasan } \\
\text { materi dengan model problem based learning }\end{array}$ & Cukup \\
\hline 3 & Menyelesaikan soal-soal pada LKS & Cukup
\end{tabular}

Berdasarkan Tabel 3, aktivitas siswa cukup baik. Di kegiatan akhir pertemuan siklus II, peneliti langsung mengadakan lembar kerja siswa. Hasil LKS siswa pada siklus kedua dapat kita lihat pada Tabel 4.

Tabel 4. Hasil Siklus II

\begin{tabular}{cc}
\hline Rata-Rata Skor Siswa & 65,26 \\
\hline Siswa Tuntas & 21 \\
\hline Siswa Tidak Tuntas & 13 \\
\hline
\end{tabular}

Berdasarkan Tabel 4, rata-rata hasil belajar siswa materi fungsi pada siklus 2 adalah 65,26 . Yang tuntas hanya 21 siswa dengan persentase $61,8 \%$, sedangkan siswa yang belum tuntas ada 13 siswa dengan persentase 38,2\%. Setelah mengkaji hasil siklus 2 ternyata masih di bawah KKM yang telah ditentukan yaitu 68, maka dilanjutkan lagi pada siklus III.

Untuk siklus III ada dua kali pertemuan. Pertemuan ini dilaksanakan pada hari Jumat, tanggal 16 januari 2019. Adapun hasil observasi aktivitas siswa pada pertemuan kedua siklus III dapat dilihat pada Tabel 5.

Tabel 5. Observasi Aktivitas Siswa Siklus III

\begin{tabular}{clc}
\hline No & \multicolumn{1}{c}{ Fokus Pengamatan } & Siswa \\
\hline 1 & Motivasi siswa mengikuti pembelajaran & Baik \\
\hline 2 & $\begin{array}{l}\text { Memperhatikan dan mengikuti penjelasan materi } \\
\text { dengan model problem based learning }\end{array}$ & Baik \\
\hline 3 & Menyelesaikan soal-soal pada LKS & Baik \\
\hline
\end{tabular}

Berdasarkan Tabel 5, aktivitas siswa sudah baik. Di kegiatan akhir pertemuan siklus III, peneliti langsung mengadakan lembar kerja siswa. Hasil LKS siswa pada siklus kedua dapat kita lihat pada Tabel 6. 
Tabel 6. Hasil Siklus 3

\begin{tabular}{cc}
\hline Rata-Rata Skor Siswa & 70,68 \\
\hline Siswa Tuntas & 25 \\
\hline Siswa Tidak Tuntas & 9
\end{tabular}

Berdasarkan Tabel 6, hasil belajar metematika pada siklus III ini menunjukkan peningkatan yang sangat baik, maka peneliti tidak perlu melanjutkan penelitian berikutnya. Namun ada 9 siswa yang belum tuntas tetap menjadi prioritas guru, sehingga siswa yang belum tuntas ini dapat memahami materi fungsi.

Setelah dilaksanakan penelitian tindakan kelas dengan model problem based learning maka terlihat adanya peningkatan dalam hasil belajar matematika materi fungsi. Peningkatan hasil belajarnya dapat dilihat pada Tabel 7.

Tabel 7. Perbandingan Hasil Belajar Siklus I, Siklus II dan Siklus III

\begin{tabular}{ccccc}
\hline \multirow{2}{*}{ Nilai } & & \multicolumn{3}{c}{ Hasil Pembelajaran } \\
\cline { 3 - 5 } & Kategori & Siklus I & Siklus II & Siklus III \\
\hline $80-100$ & Tinggi & & $13(38,2 \%)$ & $11(32,3 \%)$ \\
\hline $65-79$ & Sedang & $1(2,8 \%)$ & $8(23,6 \%)$ & $14(41,2 \%)$ \\
\hline $0-64$ & Rendah & $33(97,2 \%)$ & $13(38,2 \%)$ & $9(26,5 \%)$ \\
\hline Jumlah Siswa & 34 & 34 & 34 \\
\hline Rata-rata & $28,48 \%$ & $65,26 \%$ & $71,81 \%$ \\
\hline Kategori & Rendah & Sedang & Baik
\end{tabular}

\section{KESIMPULAN}

Berdasarkan hasil penelitian dan pembahasan maka dapat disimpulkan bahwa dengan penggunaan model problem based learning dapat meningkatkan hasil belajar dan motivasi siswa dalam materi fungsi pada siswa kelas X IPS SMAN 1 Mande Kabupaten Cianjur Tahun Pelajaran 2018/2019, Kegiatan pembelajaran dengan penggunaan model problem based learning dapat meningkatkan pembelajaran yang aktif dan menyenangkan, dan secara keseluruhan kelas dapat dikatakan tuntas.

\section{REFERENSI}

Anggriani, A., \& Septian, A. (2019). Peningkatan Kemampuan Komunikasi Matematis dan Kebiasaan Berpikir Siswa Melalui Model Pembelajaran IMPROVE. IndoMath: Indonesia Mathematics Education, 2(2), 105-116. https://doi.org/10.30738/indomath.v2i2.4550

Julyanasari, N., Praja, E. S., Noto, M. V., Sunan, U., \& Djati, G. (2019). Problem Based Learning Model on The Ability of Students Mathematical Connection. PRISMA, 8(2), 167-172. https://doi.org/10.35194/jp.v8i2.400

Lee, J. (2015). "Oh, I just had it in my head": Promoting mathematical communications in early childhood. Contemporary Issues in Early Childhood, 16(3), 284-287. https://doi.org/10.1177/1463949115600054

Maskur, R., Sumarno, Rahmawati, Y., Pradana, K., Syazali, M., Septian, A., \& Palupi, E. 
K. (2020). The effectiveness of problem based learning and aptitude treatment interaction in improving mathematical creative thinking skills on curriculum 2013. European Journal of Educational Research, 9(1), 375-383. https://doi.org/10.12973/eu-jer.9.1.375

Muslim, S. (2014). Pengaruh Penggunaan Metode Student Facilitator And Explaining dalam Pembelajaran Kooperatif terhadap Kemampuan Pemecahan Masalah Matematik dan Kemampuan Berpikir Kritis Matematik Siswa SMK di Kota Tasikmalaya. Jurnal Pendidikan Dan Keguruan, 1(1), 65-72.

Novtiar, C., \& Aripin, U. (2017). Meningkatkan Kemampuan Komunikasi Matematis Dan Kepercayaan Diri Siswa SMP Menggunakan Pendekatan Contextual Teaching And Learning. Jurnal Prisma Universitas Suryakancana, VI(2), 119-131.

Putra, J. D. (2017). Learning Cycle 5E Dalam Meningkatkan Kemampuan Komunikasi Matematis Dan Self-Regulated Learning Matematika. Prisma, 6(1), 43-56. https://doi.org/10.35194/jp.v6i1.27

Rahmadani, N., \& Anugraheni, I. (2017). Peningkatan Aktivitas Belajar Matematika Melalui Pendekatan Problem Based Learning Bagi Siswa Kelas 4 Sd. Scholaria: $\begin{array}{llll}\text { Jurnal Pendidikan } & \text { Dan }\end{array}$ https://doi.org/10.24246/j.scholaria.2017.v7.i3.p241-250

Septian, A., \& Rizkiandi, R. (2017). Penerapan Model Problem Based Learning (Pbl) terhadap Peningkatan Kemampuan Berpikir Kreatif Matematis Siswa. PRISMA, 6(1). https://doi.org/10.35194/jp.v6i1.22

Simarmata, A. M., Wibowo, M. R. H., Hutajulu, M., \& Hendriana, H. (2018). Motivasi Belajar Siswa Smp Dengan Menggunakan. VII(2), 135-144.

Umar, W. (2012). Membangun Kemampuan Komunikasi Umar, W. (2012). Membangun Kemampuan Komunikasi Matematis dalam Pembelajaran Matematika. Jurnal Infinity, 1(1), 1-9. Retrieved from http://ejournal.stkipsiliwangi.ac.id/index.php/infinity/article/view/2\%5Cnhttp://e-journal.

Jurnal Infinity, 1(1), 1-9. https://doi.org/10.22460/infinity.v1i1.2

Wardani, S., Widodo, A. T., \& Priyani, N. E. (2011). Peningkatan Hasil Belajar Siswa Melalui Pendekatan Keterampilan Proses Sains Berorientasi Problem-Based Instruction. Jurnal Inovasi Pendidikan Kimia, 3(1), 391-399.

Widayanti, L. (2013). PROBLEM BASED LEARNING PADA SISWA KELAS VIIA MTS NEGERI DONOMULYO KULON PROGO TAHUN PELAJARAN 2012 / 2013. XVII(April), 32-35.

Wijayanto, A. D., Fajriah, S. N., \& Anita, I. W. (2018). Analisis Kemampuan Komunikasi Matematis Siswa Smp Pada Materi Segitiga Dan Segiempat. Jurnal Cendekia : Jurnal Pendidikan Matematika, 2(1), 97-104. https://doi.org/10.31004/cendekia.v2i1.36 